\title{
Changes in the composition of hunting catches in southeastern Cameroon: a promising approach for collaborative wildlife management between ecologists and local hunters
}

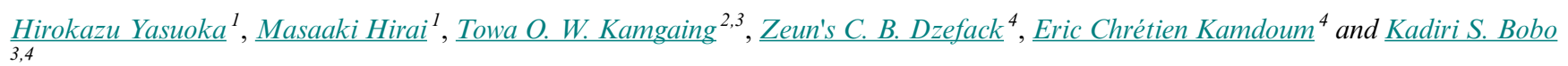

\begin{abstract}
In recent years, both depletion of wild animals and declining food supply have threatened the livelihoods of people inhabiting the forests of the Congo Basin, and rendered the bushmeat trade a national and global concern. Because initial approaches to wildlife management were criticized for lacking consideration of the customary rights of local people, a variety of projects have been proposed to ensure their active participation in management initiatives. However, unfamiliar with the concepts of conservation ecology, local people have found it difficult to contribute effectively. This paper proposes an approach to monitor the status of fauna, based on the ratio of blue duikers (Philantomba monticola) to medium-sized duikers (Cephalophus spp.) for the total number of hunting catches (the catch $\mathrm{B} / \mathrm{M}$ ). Analysis of changes in the composition of hunting catches across multiple sites in southeastern Cameroon revealed the following trends: (1) without substantive human intervention, i.e., hunting pressure and forest disturbance, medium-sized duikers were densely distributed while blue duikers were sparse, so that the catch B/M was low; (2) under moderate human intervention, blue duikers became more densely distributed while the original density of medium-sized duikers was maintained, so that the catch B/ M increased; (3) with extensive human intervention in specific areas, medium-sized duikers became sparsely distributed while a relatively high density of blue duikers was maintained, so that the catch B/M increased significantly and a mosaic of different compositions of duikers was formed; and (4) with extensive human intervention extending over the specific extensive area, both medium-sized and blue duikers became sparse. It appears that the catch B/M predicts changes in the status of game animals and of the background wild fauna, and is both a sufficiently reliable variable for ecologists and perceptible for local people. Furthermore, this approach has the potential to cultivate a relationship of trust between ecologists and local people, which is indispensable in establishing effective collaborative wildlife management.
\end{abstract}

Key Words: Baka Pygmy; Bantu farmer; blue duiker (Philantomba monticola); catch B/M; medium-sized duiker (Cephalophus spp.)

\section{INTRODUCTION}

The Congo Basin Forest covers an area of approximately 150-170 million hectares, representing the world's second largest expanse of tropical forest after the Amazon (Debroux et al. 2007). The forest attracts global attention for its high biological diversity, including rare and endangered mammals such as gorillas, chimpanzees, and forest elephants. The people living in this region depend heavily on forest resources for food, fuels, medicine, tools, ornaments, and other material culture. Wild animals and bushmeat are important protein and income sources because of the limited availability of livestock in the forest.

In recent years, both depletion of wild animals and declining food supply have threatened the livelihoods of these people and rendered the bushmeat trade a national and global concern (Wilkie and Carpenter 1999, Robinson and Bennett 2000, Fa et al. 2002, 2005, Bennett et al. 2007, Davies and Brown 2007, Nasi et al. 2008, 2011, Fa and Brown 2009, Ichikawa 2014a). In southeastern Cameroon, logging began on a small scale during the 1970s and was stimulated by the devaluation of the CFA franc in 1994, which significantly reduced the cost of timber production for foreign companies. The area under logging in Cameroon, including both actual and planned areas, expanded from just $8 \%$ in 1959 to account for $76 \%$ of the total forest area by 1999 (Bikie et al. 2000, Ichikawa 2006). The logging road network was rapidly expanded and facilitated access for poachers and bushmeat traders to inner forest areas. The people inhabiting the forest, whose abilities to work in the forest were well developed, were engaged in the bushmeat trade network (Yasuoka 2006a).

In parallel with the expansion of the logging industry, southeastern Cameroon caught the attention of conservation organizations. A wildlife management project, which covers $23,000 \mathrm{~km}^{2}$, has been in place since the late 1990s. Based on the project's zoning plan, southeastern Cameroon was divided into Permanent and non-Permanent Forest Estates (Hoare 2006, Lewis 2012, Mertens et al. 2012). The Permanent Forest Estate covers more than three-fifths of the total area of southeastern Cameroon, and currently includes 3 national parks (NPs; Lobéké NP, founded in 2001, and Boumba-Bek and Nki NPs, founded in 2005; see Fig. 1) and 10 sport-hunting zones, which were formerly allocated to 22 logging concessions; the non-Permanent Forest Estate is made up principally of agroforestry zones, upon which 14 community-hunting zones (CHZs) are superimposed (Njounan-Tegomo et al. 2012).

However, scientists working for the World Wildlife Fund, which funded this project, reported that the zoning process had not guaranteed optimal involvement of the local population, especially the Baka Pygmy, who rarely attend public gatherings and are less inclined to express their opinions frankly in the presence of their Bantu neighbors (Njounan-Tegomo et al. 2012). Moreover, the zoning process, which mostly depended on aerial photographs, took only farming land into account; thus, the forest

${ }^{1}$ Center for African Area Studies, Kyoto University, ${ }^{2}$ Graduate School of Asian and African Area Studies, Kyoto University, ${ }^{3}$ School for the Training of Wildlife Specialists Garoua, ${ }^{4}$ Department of Forestry, University of Dschang 
used by the Baka, who lead a seminomadic lifestyle, was largely ignored (Hoare 2006, Lewis 2012). As a result, the creation of the NPs, prohibiting any intervention that can alter the appearance, composition, and natural evolution of the area, including camping, farming, hunting, and cutting trees, imposed a significant restriction on the Bakas' use of forest resources (Hattori 2005, Ichikawa 2006, Yasuoka 2014). As Yasuoka (2014) argued, the approaches of local people to hunting emerge from context and history, including interactions between people and wild animals, the changing role of hunting in people's livelihoods, changes in the availability of tools, the development of economic and social relationships with neighboring populations, and importantly, involvement with the expanding bushmeat trade networks. Therefore, the strict enforcement of hunting regulations affects activities that share a common history and context, and makes earning a livelihood more difficult.

Fig. 1. Map of southeastern Cameroon showing the three national parks and community hunting zones (CHZs) 13 and 14. In addition to the main roads shown, there are many secondary roads, most of which are constructed and maintained by logging companies. NP indicates national park.

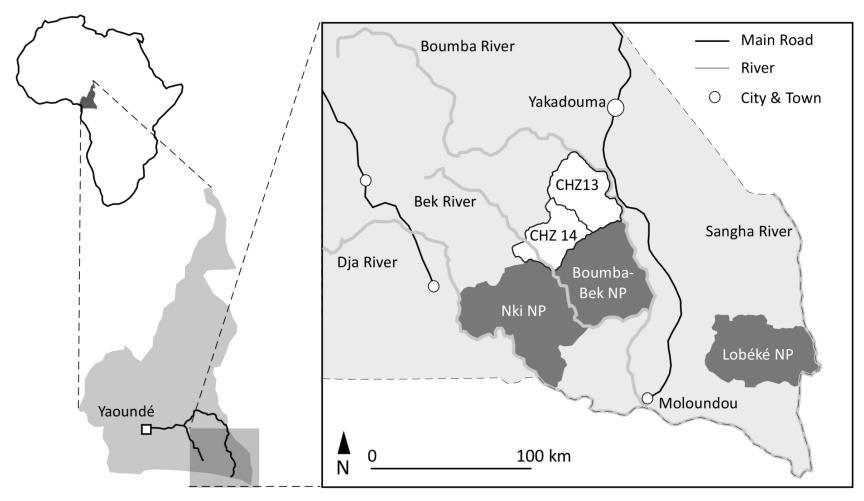

In an attempt to address the situation, a variety of projects were proposed for developing a management plan that respected the customary rights of the Baka and ensured their active participation in the planning and management process (Lewis 2012, Njounan-Tegomo et al. 2012, Ichikawa 2014a, 2014b). However, the local people, unfamiliar with the concepts of conservation ecology (e.g., intrinsic rate of increase, carrying capacity, maximum sustainable harvest rate) encountered difficulty in becoming effectively involved in the management initiatives. Even with the concept of animal density, it proved difficult for the people to reflect on the consequences of their own activities. Therefore, it is crucial to find a viable point of departure that renders the participation of local people more practical and meaningful.

Because duikers are the major game animals in the area (Yasuoka 2006a) as well as throughout the Congo Basin (Wilkie and Carpenter 1999), this paper focuses on duiker hunting. First, we examine changes in the composition of hunting catches, focusing on the ratio of blue duikers (Philantomba monticola) to mediumsized duikers (Cephalophus spp.), i.e., the catch B/M ratio. Next, we suggest that changes in this ratio can be used as an indicator to monitor the status of local fauna. If the catch $\mathrm{B} / \mathrm{M}$ is sufficiently reliable for ecologists and can be perceived by local people, it can act as a mediator between the actors and possesses the potential to cultivate a relationship of trust between them, which is indispensable in establishing effective collaborative wildlife management.

\section{STUDY AREA AND LOCAL POPULATIONS}

\section{Southeastern Cameroon}

Southeastern Cameroon, with an area of approximately 23,000 $\mathrm{km}^{2}$, is covered with tropical rainforest that sits on gently rolling hills at an altitude of 400-600 $\mathrm{m}$ above sea level. The mean annual temperature is around $24^{\circ} \mathrm{C}$ and is relatively constant year-round, and the mean annual rainfall at Yokadouma is about $1500 \mathrm{~mm}$ (Ekobo 1995). The mean monthly rainfall in the dry season (from December to February) is less than $50 \mathrm{~mm}$, whereas in the rainy season (from March to November) it is normally more than 100 $\mathrm{mm}$, although it typically becomes dryer in July. This area contains a high density of wildlife, with more than 40 species of large- and medium-sized mammals, 120 fish species, and 305 bird species, as well as 831 plant species belonging to 111 families (Ekobo 1998, Nzooh-Dongmo et al. 2002).

The vegetation in southeastern Cameroon is a mixture of evergreen and semideciduous forests (Letouzey 1985). Around the settlements, a mosaic of patches of mature forest, old secondary forest, fallow, cocoa agroforest, and crop fields has been created through the long-term agricultural practices of the local people. Yasuoka (2009) pointed out that even at a distance of about $40 \mathrm{~km}$ from the village, the forest composition appears to have been affected by historical practices of shifting cultivation. In addition, logging has introduced a different kind of disturbance to the forest since a couple of decades ago.

\section{The Baka Pygmy and the Bantu peoples}

Southeastern Cameroon is inhabited by around 110,000 people. These include the Bantu peoples, the Baka Pygmy, and immigrants from other parts of Cameroon or neighboring countries, who constitute roughly $60 \%, 25 \%$, and $15 \%$ of the total population, respectively (Njounan-Tegomo et al. 2012).

The term "Bantu" is derived from the name of the largest subbranch of the African language family and is used locally to refer to the 10 or more ethnic groups living in this area, usually regardless of the difference between Bantu-speaking and Ubangian-speaking farmers. Their main livelihood activity is slash-and-burn agriculture, in which they grow plantain, cassava, maize, and groundnuts, as well as practicing cacao agroforestry. Hunting, fishing, and gathering of nontimber forest products are also important livelihood activities. Some are employed in additional activities, such as government services, logging, sport hunting, and mining. Animal husbandry is poorly developed.

The only "Pygmy" living in this area are the Baka, who were predominantly hunter-gatherers before the 1950s, when they were still leading a nomadic lifestyle in small camps scattered throughout the forest. Since the 1930s, the French-mandated government has promoted the sedentarization of the population in the area, and the Cameroonian government has continued this policy following independence in 1960 (Althabe 1965). Today, the Baka live more or less in sedentary settlements located along the roads, although some still spend several months of the year living in the forest (Yasuoka 2012). 
Table 1. Characteristics of duikers in southeastern Cameroon. ${ }^{\dagger}$

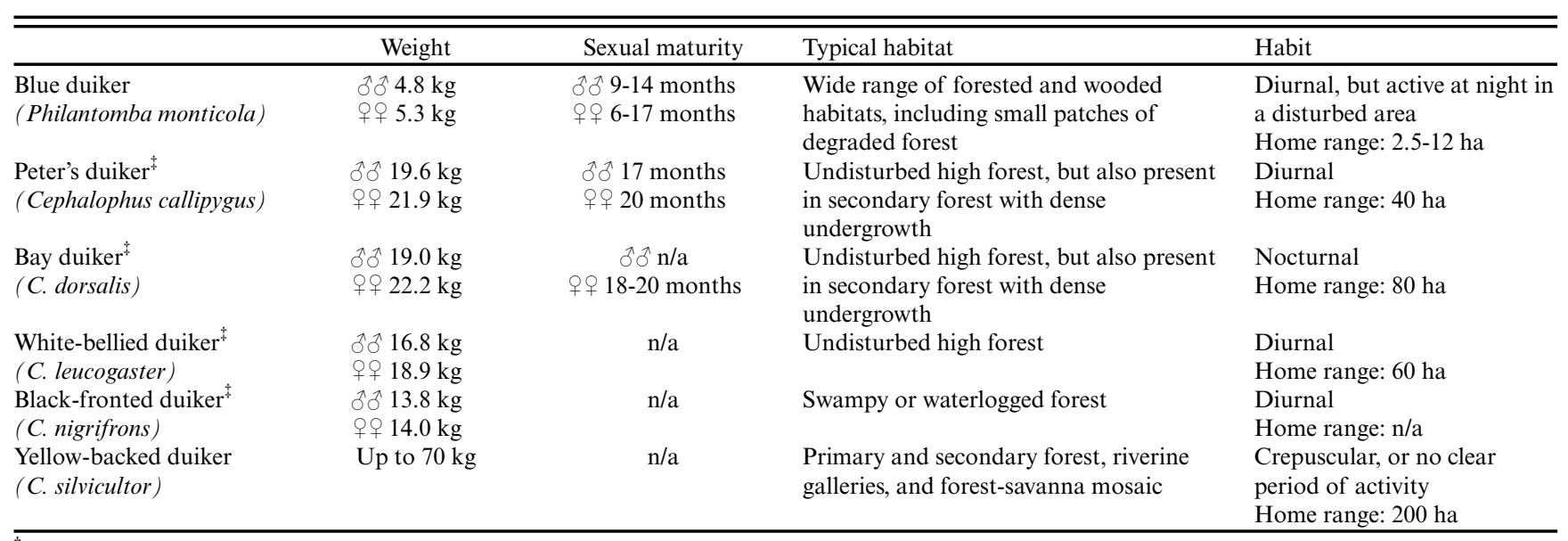

${ }^{\dagger}$ From Kingdon and Hoffmann (2013) and Wilson (2001).

Medium-sized duikers.

$\mathrm{n} / \mathrm{a}$ indicates not available.

The Bantu peoples and the Baka have close, but unequal, social and economic relationships with one another, and the Bantu act as masters, or patrons, of the Baka. The Baka generally obey the orders of the Bantu, especially in providing low-cost labor. However, when they lose patience with the arrogant attitude of the Bantu, they leave the village and spend months at a time in the forest. These complex social and power relationships among different ethnic groups in the local area make their effective involvement in wildlife management initiatives difficult. It is important to take steps to ensure that the implementation of a management program does not end up reinforcing the existing unequal interethnic and social relationships; otherwise, the Baka who exist in a subordinate relationship to the Bantu will not see any positive benefit from the wildlife management and development programs (Ichikawa 2006, Hattori 2014).

\section{Hunting technologies}

The hunting technologies of the Pygmies of the Congo Basin have been influenced by the availability of hunting instruments, the primary sources of which were likely neighboring farmers (Hewlett 1996). For example, the Mbuti Pygmy of the Ituri Rainforest in the Democratic Republic of the Congo practice net hunting, whereas the Efe Pygmy, who live in the same area, never practice net hunting and prefer bows and arrows. Some researchers have argued that this is because the neighboring farmers of the Efe have never conducted net hunting, so the nets have not been made available to them (Harako 1976, Bailey and Aunger 1989).

Traditionally, the Baka hunted primarily with spears, whereas today the major hunting method is snares made with steel wires (Yasuoka 2006a, 2006b, 2014). An elderly Baka individual, aged about 60 years, commented that people had formerly constructed snares with plant material, but steel wires became available for use in the snares during his childhood in the 1960s. Almost all snares set by the Baka are foot snares. When an animal steps on the snare, a bent rod springs loose, causing a wire fastened to the rod to wrap around the animal's foot and lift the animal into the air. Snares are usually set $10-30 \mathrm{~m}$ apart along animal trails, although sometimes two or three snares are set side by side. Because setting a snare requires around 30 minutes, men set a maximum of about 10 snares per day. Hunters visit their snares every three days because trapped animals begin to decompose within a couple of days of death.

The Bantu generally use snares and guns to hunt. Snare hunting is more suitable for a sedentary lifestyle than for a nomadic lifestyle. When Bantu hunters carry out snare hunting at forest camps, the Baka often accompany them. It is likely that Bantu hunters developed the technology and subsequently the Baka learned it from them. Previously, Bantu hunters hunted monkeys using crossbows with poisoned arrows, whereas today they use guns, which are too expensive for the Baka to buy. The Bantu gun owners often use Baka men to hunt animals with their firearms. Shotgun hunting is entrusted to a large number of adult Baka men, whereas rifle hunting is entrusted to only a few skillful Baka for elephant hunting. Notably, because the Bantu practice a larger variety of livelihood activities, only some of the men are engaged in hunting. Some set hundreds of snares, others hunt with guns with the aid of Baka, some do both, and others do not hunt at all.

\section{Duikers in southeastern Cameroon}

The most frequently hunted animals in this area are duikers, species included in the family Cephalophini, which are forest antelopes distributed uniquely in Africa. This group comprises 3 genera and 19 species (Kingdon and Hoffmann 2013). As shown in Table 1, six species inhabit southeastern Cameroon (Ekobo 1998, Bobo et al. 2014): blue duiker, Peter's duiker (Cephalophus callipygus), bay duiker ( $C$. dorsalis), white-bellied duiker $(C$. leucogaster), black-fronted duiker (C. nigrifrons), and yellowbacked duiker ( $C$. silvicultor). All of these species are fruit eaters, but they also consume seeds, leaves, the bark of shrubs, fungi, ground moss, etc. (Kingdon and Hoffmann 2013).

The blue duiker, weighing about 4 to $6 \mathrm{~kg}$, is the smallest duiker and represents one of the three most hunted duikers in the study area. The other two most hunted duikers are Peter's duiker and 
the bay duiker, which are medium-sized duikers, reaching a weight of about $20 \mathrm{~kg}$. They closely resemble each other, but the former is diurnal whereas the latter is nocturnal.

The white-bellied duiker is also a diurnal, medium-sized species, but because it only appears in undisturbed high forest, it is rarely hunted. The black-fronted duiker is smaller than the other medium-sized duikers and lives in swampy areas and waterlogged forest. The yellow-backed duiker, which reaches $70 \mathrm{~kg}$, is the largest duiker and is crepuscular, or has no clear period of activity. Like the white-bellied duiker, these latter two species are also rarely hunted.

To facilitate comparison with the blue duiker, we grouped the four duiker species with similar body sizes (about 15-20 kg) as mediumsized duikers because it is difficult to distinguish the dung and tracks of different medium-sized duikers (van Vliet et al. 2008).

\section{METHODS}

The data we analyzed were obtained between 2002 and 2014 in villages in CHZs 13 and 14, an area in the south adjacent to Nki NP and Boumba-Bek NP (Figs. 1 and 2). Five villages are located in each of CHZs 13 and 14 along a secondary road that passes through these CHZs from northeast to southwest, branching off an unpaved highway between Yokadouma and Moloundou. The major Bantu people in this area are the Konabembe. The villages in CHZ 13 (Biwala-1, Massea, Zoka Diba, Bintom, and Gribé) contain a total of around 4350 people (1250 Baka and 3100 Konabembe and others), whereas CHZ 14 (Som Ancien, Gouenepoum Ancien, Malea Ancien, Zoulabot Ancien [ZA], and Ngato Ancien) is inhabited by only about 850 people (690 Baka and 160 Konabembe and others; Halle 2000, Fogue and Defo 2006, Toda 2014). With areas of 1130 and $877 \mathrm{~km}^{2}$, respectively, the population densities of CHZs 13 and 14 are 3.8 and 1.0 people per square kilometer.

Fig. 2. Map showing the research sites. In addition to the centers of the villages shown, there are scattered small settlements; many are located in community hunting zone (CHZ) 13. NP indicates national park.

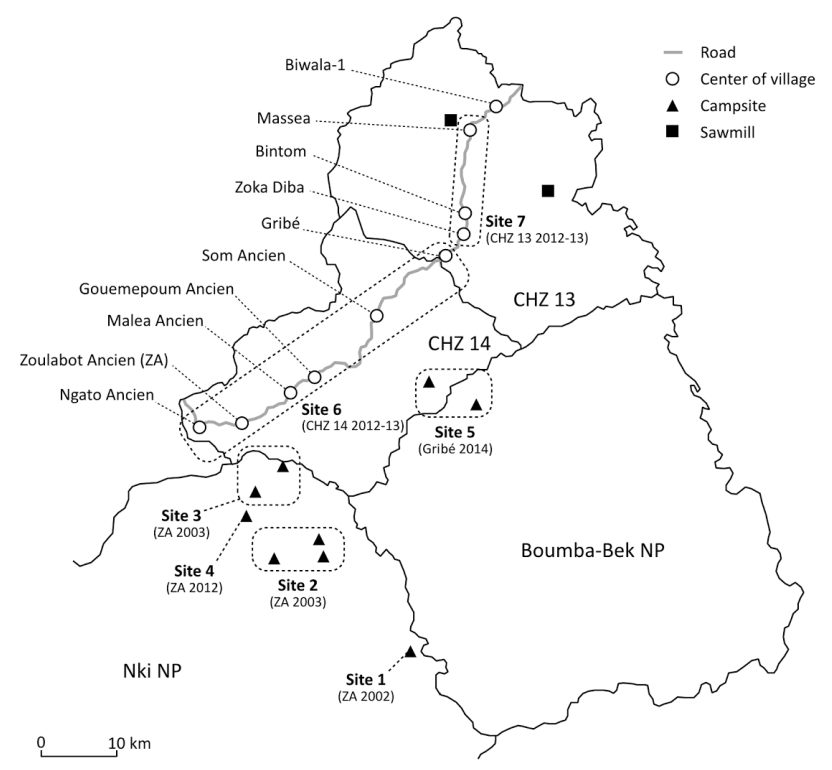

To compare the compositions of the hunting catches in this area, we arranged seven data sets collected in sites 1-7, which were exposed to different levels of hunting pressure (Fig. 2). In sites $1-4$, the hunting catches of the Baka in 2002, 2003, and 2012 were recorded by one of the authors (HY) in ZA, a village located in the southwestern part of CHZ 14. The hunting area of the people in ZA overlaps significantly with Nki NP, whose border was demarcated $5 \mathrm{~km}$ south of the village. At site 1 (ZA 2002), data were collected by direct observation during six weeks in 2002 in a large-scale camp with 89 people built at a site $40 \mathrm{~km}$ from the village. All animals hunted during the duration of the camp were weighed and identified on-site following Kingdon (1997). The number of snares and days that they remained set were also recorded, so that the effort required for a single animal catch (snare days/catch) and the effort per unit weight of catch (snare days/kilogram) could be calculated.

In sites 2-4, we used interviews to record data on snare lines about two months after the installation of the snares. The Baka demonstrated an accurate remembrance of the animals caught in each snare. In 2003, data were collected at five campsites, where snare hunting was eagerly carried out during a boom in the bushmeat trade. To compare the difference in catch with distance from the village, the campsites were divided into two areas; site 2 (ZA 2003 remote), including three campsites located around 20 $\mathrm{km}$ from the village; and site 3 (ZA 2003 nearby), including two campsites located within $10 \mathrm{~km}$ of the village. In 2012, data were collected at site 4 (ZA 2012), built at a distance of $12 \mathrm{~km}$ from the village. Although the weights of the animals hunted during these sites were unknown, the numbers of snares and days that they remained set were recorded, so that the effort required for a single catch could be calculated. When the weights of the duikers were required for analysis, we used a weight of $16 \mathrm{~kg}$ for mediumsized duikers and $4 \mathrm{~kg}$ for blue duikers.

In site 5 (Gribé 2014), one of the authors (MH) recorded the hunting catches by Baka living in Gribé, a village located in the vicinity of the border between CHZs 13 and 14. Many hunters in Gribé entered the forest in CHZ 14. Data were collected by direct observation for several weeks in two campsites built at 17 and 22 $\mathrm{km}$ from the village: one in $\mathrm{CHZ} \mathrm{14}$, and the other in BoumbaBek NP. All animals hunted during the camp were identified and weighed, and the number of snares and days that they remained set were recorded.

Finally, in 2012 and 2013, four of the authors (TK, ZD, EK, and $\mathrm{KB}$ ) carried out a survey on hunting done by the Konabembe in an extensive area across CHZs 13 and 14. In nine villages (excluding Biwala-1 from the above-mentioned villages), a total of 122 hunters (7-38 in each village) out of 236 active hunters were monitored for an average of 7.4 days, or 899 hunter days, and the captured animals were recorded. Because the monitoring was carried out based on the village, it should be noted that most hunted animals were observed closer to the village areas than they were with the Baka hunters in the forest camps. The 9 villages were divided into 2 groups according to the $\mathrm{CHZ}$ in which each village was located, with the exception of Gribé, which was assigned to $\mathrm{CHZ} 14$ because the hunters were more active in $\mathrm{CHZ}$ 14. Consequently, site 6 (CHZ 14 2012-2013) and site 7 (CHZ 13 2012-2013) were established. 
Table 2. Catch and its proportion to the total catch for animal species hunted with snares by the Baka at sites 1-5.

\begin{tabular}{|c|c|c|c|c|c|c|c|c|c|c|}
\hline & \multirow{2}{*}{\multicolumn{2}{|c|}{$\begin{array}{c}\text { Site } 1 \\
(\text { ZA 2002) } \\
40 \mathrm{~km} \text { from } \mathrm{ZA} \\
\end{array}$}} & \multirow{2}{*}{\multicolumn{2}{|c|}{$\begin{array}{c}\text { Site } 2 \\
{\text { (ZA 2003 remote })^{\S}}^{\S} 20 \mathrm{~km} \text { from } \mathrm{ZA} \\
\end{array}$}} & \multirow{2}{*}{\multicolumn{2}{|c|}{$\begin{array}{c}\text { Site } 3 \\
{\text { (ZA } 2003 \text { nearby })^{\S}}^{\S 10 \mathrm{~km} \text { from } \mathrm{ZA}} \\
\end{array}$}} & \multirow{2}{*}{\multicolumn{2}{|c|}{$\begin{array}{c}\text { Site } 4 \\
(\text { ZA 2012) } \\
12 \mathrm{~km} \text { from } \mathrm{ZA} \\
\end{array}$}} & \multirow{2}{*}{\multicolumn{2}{|c|}{$\begin{array}{c}\text { Site } 5 \\
(\text { Gribé 2014) } \\
20 \mathrm{~km} \text { from Gribé }\end{array}$}} \\
\hline & & & & & & & & & & \\
\hline & Catch & Prop & Catch & Prop & Catch & Prop & Catch & Prop & Catch & Prop \\
\hline $\begin{array}{l}\text { Blue duiker } \\
\text { (Philantomba monticola) }\end{array}$ & 2 & 0.02 & 22 & 0.05 & 13 & 0.07 & 18 & 0.30 & 65 & 0.50 \\
\hline $\begin{array}{l}\text { Peter's duiker }{ }^{\dagger} \\
\text { (Cephalophus callipygus) }\end{array}$ & 38 & 0.42 & 285 & 0.59 & 118 & 0.65 & 26 & 0.43 & 16 & 0.12 \\
\hline $\begin{array}{l}\text { Bay duiker }{ }^{\dagger} \\
\text { (C. dorsalis) }\end{array}$ & 21 & 0.23 & 51 & 0.11 & 16 & 0.09 & 4 & 0.07 & 8 & 0.06 \\
\hline $\begin{array}{l}\text { White-bellied duiker }{ }^{\dagger} \\
\text { (C. leucogaster) }\end{array}$ & 5 & 0.05 & 8 & 0.02 & 5 & 0.03 & & & 1 & 0.01 \\
\hline $\begin{array}{l}\text { Black-fronted duiker }{ }^{\dagger} \\
\text { (C. nigrifrons) }\end{array}$ & 1 & 0.01 & 1 & 0.00 & 2 & 0.01 & 2 & 0.03 & 2 & 0.02 \\
\hline $\begin{array}{l}\text { Yellow-backed duiker } \\
\text { (C. silvicultor) }\end{array}$ & 9 & 0.10 & 28 & 0.06 & 6 & 0.03 & 2 & 0.03 & & \\
\hline $\begin{array}{l}\text { Red river hog } \\
\text { (Potamochoerus porcus) }\end{array}$ & 3 & 0.03 & 34 & 0.07 & 8 & 0.04 & 3 & 0.05 & & \\
\hline $\begin{array}{l}\text { Brush-tailed porcupine } \\
\text { (Atherurus africanus) }\end{array}$ & & & 1 & 0.00 & 2 & 0.01 & & & 22 & 0.17 \\
\hline $\begin{array}{l}\text { Giant pouched rat } \\
\text { (Cricetomys sp.) }\end{array}$ & & & 1 & 0.00 & & & & & & \\
\hline Other & 12 & 0.13 & 51 & 0.11 & 11 & 0.06 & 6 & 0.10 & 15 & 0.12 \\
\hline Total & 91 & 1.00 & 481 & 1.00 & 181 & 1.00 & 61 & 1.00 & 129 & 1.00 \\
\hline
\end{tabular}

As mentioned above, the density of human habitation is fourfold higher in $\mathrm{CHZ} 13$ than in $\mathrm{CHZ}$ 14. In CHZ 13, a secondary road along which cars arrive from the regional commercial center of Yokadouma has existed since the 1960s, so the villages have been connected since this time to the town's bushmeat market. Furthermore, in the northern and northeastern parts of $\mathrm{CHZ} 13$, two sawmills have been in operation for several decades, employing large numbers of laborers who consume considerable quantities of bushmeat. It is therefore likely that higher hunting pressure has continued for longer in $\mathrm{CHZ} 13$ than in $\mathrm{CHZ} \mathrm{14,}$ where the road was constructed in 2001-2002. When the logging road was opened in $\mathrm{CHZ} 14$, the bushmeat catch increased by a factor of 5-10 (Yasuoka 2006a). The boom in the bushmeat trade, however, decreased to some extent, but did not disappear, after control of bushmeat transport was strengthened in the mid-2000s when the NPs were established.

Based on these events, the hunting pressure that has accumulated at each site can be placed in the following order: site 1 (ZA 2002) < site 2 (ZA 2003 remote) < site 3 (ZA 2003 nearby) < site 4 (ZA 2012 ) < site 5 (Gribé 2014) < site 6 (CHZ 14 2012-2013) < site 7 (CHZ 13 2012-2013).

\section{RESULTS}

\section{Catches by snare hunting by the Baka in forest camps}

In site 1 (ZA 2002), the camp built by the Baka $40 \mathrm{~km}$ from the village, snare hunting yielded 91 animals, in which Peter's duikers accounted for $42 \%$ (38/91 catches) of the total catch, followed by bay duikers, which accounted for 23\% (21/91) (Table 2). In total, medium-sized duikers accounted for $71 \%(65 / 91)$ of the catch. In contrast, blue duikers accounted for a mere $2 \%(2 / 91)$. Similar results were observed in 2003 in site 2 (ZA 2003 remote), around $20 \mathrm{~km}$ from the village, and in site 3 (ZA 2003 nearby), within 10 $\mathrm{km}$ of the village. Medium-sized duikers accounted for $72 \%$ of the catch (345/481) for site 2 and $78 \%$ (141/181) for site 3 , whereas blue duikers accounted for 5\% (22/481) and 7\% (13/181), respectively. Among these sites, no clear differences in the major components of the catches were observed, although the catches in sites 1 and 2 contained many larger animals, such as yellowbacked duikers and red river hogs (Potamochoerus porcus).

An interesting change occurred over the 10 years between observations. At site 4 (ZA 2012), a camp built near site 3, snare hunting yielded 61 animals, in which medium-sized duikers accounted for $50 \%(30 / 61)$ of the catches, less than the proportions in the earlier sites (Table 2). The percentage of blue duikers increased to as high as $30 \%(18 / 61)$, which is a substantial increase compared with the earlier sites.

The question remains whether this result is an accidental outlier or a reflection of actual changes in the background populations of the game animals. If we examine the data from site 5 (Gribé 2014), located in an area of denser human population and therefore higher hunting pressure, blue duikers accounted for $50 \%$ $(65 / 129)$ of the total catches, whereas medium-sized duikers in contrast accounted for $21 \%(27 / 129)$, a far smaller proportion than that from sites 1-4 (Table 2). Therefore, it is reasonable to consider that the change in the catch composition, i.e., a decrease in medium-sized duikers and an increase in blue duikers, was caused by an increase in hunting pressure. 
Table 3. Single catch effort (snare days/catch) at sites 1-5.

\begin{tabular}{|c|c|c|c|c|c|c|c|c|c|c|}
\hline & \multicolumn{2}{|c|}{ Site 1} & \multicolumn{2}{|c|}{ Site 2} & \multicolumn{2}{|c|}{ Site 3} & \multicolumn{2}{|c|}{ Site 4} & \multicolumn{2}{|c|}{ Site 5} \\
\hline & \multicolumn{2}{|c|}{$\begin{array}{c}10,223 \text { snare } \\
\text { days }\end{array}$} & \multicolumn{2}{|c|}{$\begin{array}{c}50,320 \text { snare } \\
\text { days }\end{array}$} & \multicolumn{2}{|c|}{$\begin{array}{c}29,979 \text { snare } \\
\text { days }\end{array}$} & \multicolumn{2}{|c|}{$\begin{array}{c}8360 \text { snare } \\
\text { days }\end{array}$} & \multicolumn{2}{|c|}{$\begin{array}{c}\text { 14,851 snare } \\
\text { days }\end{array}$} \\
\hline & Catch & S-D/catch & Catch & S-D/catch & Catch & S-D/catch & Catch & S-D/catch & Catch & S-D/catch \\
\hline $\begin{array}{l}\text { Blue duiker } \\
\text { (Philantomba monticola) }\end{array}$ & 2 & 5112 & 22 & 2286 & 13 & 2306 & 18 & 464 & 65 & 228 \\
\hline $\begin{array}{l}\text { Medium-sized duikers } \\
\text { (Cephalophus spp.) }\end{array}$ & 65 & 157 & 345 & 146 & 141 & 213 & 32 & 261 & 27 & 550 \\
\hline Both groups of duikers & 67 & 153 & 367 & 137 & 154 & 195 & 50 & 167 & 92 & 161 \\
\hline Other & 24 & 426 & 114 & 441 & 33 & 908 & 11 & 760 & 37 & 401 \\
\hline All animals & 91 & 112 & 481 & 105 & 181 & 166 & 61 & 137 & 129 & 115 \\
\hline
\end{tabular}

S-D indicates snare days.

\section{Effort required for snaring by the Baka}

The effort required for a single catch (snare days/catch) showed no significant variation among sites 1-4 (Table 3 ). The effort for all animals was $112(10,223 / 91)$ snare days/catch for site 1,105 $(50,320 / 481)$ for site $2,166(29,979 / 181)$ for site 3 , and 137 $(8360 / 61)$ for site 4 . The effort was greatest at site 3 , most likely because the catches were recorded during the peak of the bushmeat trade. Although the value for site 4 in 2012 remained comparable with those for the sites in earlier years, the effort for blue duiker decreased from $5122(10,223 / 2)$ for site 1 to 464 $(8360 / 18)$ for site 4 , whereas that for medium-sized duiker increased from $157(10,223 / 65)$ to $261(8360 / 32)$ in the same period.

These trends are more apparent when the results from site 5 are also taken into account, where an effort of 115 snare days/catch was required for all animals and an effort of 161 snare days/catch was required for blue and medium-sized duikers; these values correspond fairly closely with those for sites 1-4 (Table 3). However, if blue and medium-sized duikers are regarded separately, the effort for blue duiker was lower $(228=14,851 / 65)$ and that for medium-sized duiker was significantly higher $(550=$ $14,851 / 27)$ than those for sites 1-4.

These results suggest that, in accordance with the increasing hunting pressure, catches of blue duiker replaced the catches of medium-sized duikers, while the effort for a single catch was maintained at a consistent level over time. It is also notable that, even when the effort for a single catch remained constant, the effort required per unit weight of catch (snare days/kilogram) decreased because of the significantly smaller weight of blue duikers (4 kg on average) compared with that of medium-sized duikers (16 kg on average). In fact, the effort for a catch of $1 \mathrm{~kg}$ for blue and medium-sized duikers combined was $21(14,851 / 701)$ snare days/kilogram for site 5 and 9 (50,320/5608)-14 (8360/584) snare days for sites 1-4 (Table 4). This disparity increased when considering all animals together: $18(14,851 / 827)$ snare days/ kilogram for site 5 but only $5(10,223 / 1930)$ snare days/kilogram for site 1 , because the catches in site 1 included many larger animals, such as yellow-backed duikers and red river hogs that sometimes reach weights of $50 \mathrm{~kg}$ or more. In contrast, in site 5 , most captured animals other than duikers were small, e.g., brushtailed porcupines (Atherurus africanus) weighing about $3 \mathrm{~kg}$, which accounted for $17 \%$ of the total catch (Table 2 ).
Catches from snare and gun hunting around the villages by the Konabembe

The hunting catches of the Konabembe were observed in sites 6 (CHZ 14 2012-13) and 7 (CHZ 13 2012-2013), including nine villages along the road running through $\mathrm{CHZs} 14$ and 13 (Fig. 2). The major difference between the Baka and the Konabembe is that the Konabembe often use guns for hunting. The majority of hunters monitored in site 7 used guns ( 21 hunters out of 36 monitored), although fewer hunters in site 6 used guns ( 15 out of 86). Although they sometimes hunt animals during stays at forest camps, the catches presented here were mainly hunted around the villages.

In site 6 , where 602 hunter days were monitored, the majority of the catches were obtained using snares; 213 animals were captured with foot snares, 44 with shotguns, and 15 using other methods (Table 5). In contrast to the results from sites 1-4 but similar to the results from site 5, blue duikers accounted for 50\% (107/213) of the total catches by snare, whereas medium-sized duikers accounted for only $17 \%$ (37/213) of the total catches by snare. It is notable that rodents comprised a considerable proportion of the catches, with brush-tailed porcupines accounting for $12 \%$ $(25 / 213)$ of the total catch.

In site 7, where 300 hunter days were monitored, 249 animals were hunted with shotguns, 42 with foot snares, and 24 using other methods, including hunting with spears and dogs, neck snares, and catching by hand (Table 5). The major targets of gun hunting in site 7 were monkeys, which accounted for $52 \%(130 / 249)$ of the total catch, and blue duikers, accounting for $41 \%(102 / 249)$. Monkeys were hunted in the daytime, whereas blue duikers were hunted at night using flashlights. In site 7, blue duikers accounted for $57 \%(24 / 42)$ of the total catches by snare, followed by giant pouched rats (Cricetomys sp.; weighing $1 \mathrm{~kg}$ ) and medium-sized duikers, accounting for $10 \%(4 / 42)$ each of the total catches by snare.

\section{DISCUSSION}

\section{Changes in the blue duiker/medium-sized duiker catch ratios} (catch B/M)

Comparison of the compositions of the hunting catches revealed a decrease in the size of hunted animals in accordance with the increase in hunting pressure, which is consistent with the general picture of hunting patterns in African rainforests (Fimbel et al. 
Table 4. Unit weight catch effort (snare days/kilogram) at sites 1-5.

\begin{tabular}{|c|c|c|c|c|c|c|c|c|c|c|}
\hline & \multicolumn{2}{|c|}{ Site 1} & \multicolumn{2}{|c|}{ Site 2} & \multicolumn{2}{|c|}{ Site 3} & \multicolumn{2}{|c|}{ Site 4} & \multicolumn{2}{|c|}{ Site 5} \\
\hline & \multicolumn{2}{|c|}{$\begin{array}{c}10,223 \text { snare } \\
\text { days }\end{array}$} & \multicolumn{2}{|c|}{$\begin{array}{c}50,320 \text { snare } \\
\text { days }\end{array}$} & \multicolumn{2}{|c|}{$\begin{array}{l}29,979 \text { snare } \\
\text { days }\end{array}$} & \multicolumn{2}{|c|}{$\begin{array}{c}8360 \text { snare } \\
\text { days }\end{array}$} & \multicolumn{2}{|c|}{$\begin{array}{c}14,851 \text { snare } \\
\text { days }\end{array}$} \\
\hline & Catch in $\mathrm{kg}$ & $\mathrm{S}-\mathrm{D} / \mathrm{kg}$ & $\begin{array}{c}\text { Catch in } \\
\mathrm{kg}\end{array}$ & $\mathrm{S}-\mathrm{D} / \mathrm{kg}$ & $\begin{array}{l}\text { Catch in } \\
\mathrm{kg}\end{array}$ & $\mathrm{S}-\mathrm{D} / \mathrm{kg}$ & Catch in $\mathrm{kg}$ & $\mathrm{S}-\mathrm{D} / \mathrm{kg}$ & $\begin{array}{c}\text { Catch in } \\
\mathrm{kg}\end{array}$ & $\mathrm{S}-\mathrm{D} / \mathrm{kg}$ \\
\hline $\begin{array}{l}\text { Blue duiker } \\
\text { (Philantomba monticola) }\end{array}$ & 7 & 1381 & $88^{\dagger}$ & 572 & $52^{\dagger}$ & 577 & $72^{\dagger}$ & 116 & 273 & 54 \\
\hline $\begin{array}{l}\text { Medium-sized duikers } \\
\text { (Cephalophus spp.) }\end{array}$ & 1034 & 10 & $5520^{\dagger}$ & 9 & $2256^{\dagger}$ & 13 & $512^{\dagger}$ & 16 & 428 & 35 \\
\hline Both groups of duikers & 1042 & 10 & $5608^{\dagger}$ & 9 & $2308^{\dagger}$ & 13 & $584^{\dagger}$ & 14 & 701 & 21 \\
\hline Other & 888 & 12 & \multicolumn{2}{|c|}{$\mathrm{n} / \mathrm{a}$} & \multicolumn{2}{|c|}{$\mathrm{n} / \mathrm{a}$} & \multicolumn{2}{|l|}{$\mathrm{n} / \mathrm{a}$} & 125 & 119 \\
\hline All animals & 1930 & 5 & \multicolumn{2}{|c|}{$\mathrm{n} / \mathrm{a}$} & \multicolumn{2}{|c|}{$\mathrm{n} / \mathrm{a}$} & \multicolumn{2}{|c|}{$\mathrm{n} / \mathrm{a}$} & 827 & 18 \\
\hline
\end{tabular}

${ }^{\dagger}$ An average of $4 \mathrm{~kg}$ was applied to the estimations for blue duiker, and $16 \mathrm{~kg}$ for medium-sized duikers.

$\mathrm{S}-\mathrm{D}$ indicates snare days.

2000, Fa et al. 2005, van Vliet and Nasi 2008a, Fa and Brown 2009, Nasi et al. 2011). At sites 1-3, where the hunting pressure was lower, medium-sized duikers weighing 15-20 kg accounted for $65 \%-78 \%$ of the total catches with snares. The proportion of medium-sized duikers in the catches decreased to $52 \%$ for site 4 , $22 \%$ for site $5,17 \%$ for site 6 , and $14 \%$ for site 7 . In contrast, the proportion of blue duikers weighing about $4 \mathrm{~kg}$ increased from $2 \%-7 \%$ for sites $1-3$ to $30 \%$ for site 4 and to approximately $50 \%$ for sites 5-7.

To examine these trends in a more quantitative manner, the catch $\mathrm{B} / \mathrm{M}$, or the ratio of blue duikers to medium-sized duikers for the total number of catches, was calculated for each site (Table 6). The catch $\mathrm{B} / \mathrm{M}$ was 0.03 (2/62) for site $1,0.06$ (22/345) for site 2, $0.09(13 / 141)$ for site 3 , and $0.56(18 / 32)$ for site 4 . It increased to $2.31(81 / 35)$ for site $5,2.89(107 / 37)$ for site 6 , and $4.00(24 / 6)$ for site 7. With gun hunting, the catch $\mathrm{B} / \mathrm{M}$ was 6.00 (12/2) for site 6 and $12.75(102 / 8)$ for site 7 . A similar trend was also observed in a study carried out around Lobéké NP, where the catch B/M was 0.19 for an area at a distance of $30 \mathrm{~km}$ or greater from the village, 0.26 at a distance of $20-30 \mathrm{~km}, 0.68$ for $10-20 \mathrm{~km}$, and 2.16 for 0-10 km (Fimbel et al. 2000).

\section{Changes in the blue duiker/medium-sized duiker density ratios (density B/M)}

Next, we considered the possible causes underlying this trend and the changes in the densities of duikers. Although it should be noted that the density estimations vary considerably depending on the method applied in the census (Wilkie and Carpenter 1999, van Vliet and Nasi 2008b, Viquerat et al. 2012), the same methods were applied in the studies that we examined. i.e., dung counting along transects set in quadrats of gravel covering the research area (Seber 1982, White and Edwards 2000), which enabled a reliable comparison between studies (but see also van Vliet et al. 2008).

According to Ekobo (1998), the densities of blue duiker were estimated at 0.1 individuals per square kilometer in the $\mathrm{Nki}$ area and at 0.4 in the Corridor area (these two areas lay within the Nki NP established later), whereas for medium-sized duikers the densities were 6.0 and 5.3 for the two areas, respectively (Table 7). The ratio of the density of blue duikers to medium-sized duikers, or the density $\mathrm{B} / \mathrm{M}$, was $0.02(0.1 / 6.0)$ for the Nki area and 0.08 $(0.4 / 5.3)$ for the Corridor area. These values were fairly close to the catch $\mathrm{B} / \mathrm{M}$ for sites $1-3$ located in this area $(0.03,0.06$, and 0.09 , shown in Table 6). This means that, at these sites, the species of duiker caught in the snares corresponded to the species composition of the combined population of all duikers.

In the mid-2000s, after the start of the bushmeat trade boom, the density of blue duiker in Nki NP was 2.8 and that of mediumsized duikers was 6.8 (Nzooh-Dongmo et al. 2006). Bobo et al. (2014) later estimated the density of blue duiker in CHZ 14 at 4.9 and of medium-sized duikers at 7.2. The density of medium-sized duikers remained comparable with the densities estimated in $\mathrm{Nki}$ NP in earlier years. However, the density of blue duiker increased significantly, yielding a density $\mathrm{B} / \mathrm{M}$ of 0.68 .

In contrast, in $\mathrm{CHZ} 13$, although the density $\mathrm{B} / \mathrm{M}$ was 0.70 , the estimated densities were much lower for both types of duiker: 1.6 for blue duiker and 2.3 for medium-sized duikers (Bobo et al. 2014). This is clearly because the hunting pressure has been much greater in $\mathrm{CHZ} 13$ than in $\mathrm{CHZ} 14$.

An important question is why the density $\mathrm{B} / \mathrm{M}$ increases under increasing hunting pressure. This is likely related to the different tolerances of the duiker species to increased hunting pressure. Because blue duikers are four- to fivefold lighter than mediumsized duikers, they reach reproductive age earlier (Table 1). Blue duikers are thus better able to withstand higher hunting pressure than the larger duikers (Hart and Kingdon 2013). Consequently, the greater the hunting pressure, the more blue duikers replace medium-sized duikers. In addition, blue duikers tolerate and even thrive in a range of human-modified habitats, including in the vicinity of human settlements, and often persist well in small habitat patches (Hart and Kingdon 2013). Entangled vegetation of secondary regrowth after shifting cultivation or human habitation provides small blue duikers with refuges by reducing the range of predators. Consequently, a compensatory change (Wright 2003, Fa and Brown 2009) occurs between blue and medium-sized duikers.

\section{Deviation of the catch $\mathrm{B} / \mathrm{M}$ from the density $\mathrm{B} / \mathrm{M}$}

Based on the above discussion, it would be expected that the catch $\mathrm{B} / \mathrm{M}$ would increase together with increasing density $\mathrm{B} / \mathrm{M}$, which is affected by increasing hunting pressure. However, Tables 6 and 7 show that the catch $\mathrm{B} / \mathrm{M}$ begins to deviate from the density $\mathrm{B} /$ $\mathrm{M}$ in areas with considerably higher hunting pressure; the catch 
Table 5. Catch and proportion to the total catch for animal species hunted by the Konabembe at sites 6 and 7 .

\begin{tabular}{|c|c|c|c|c|c|c|c|c|c|c|c|c|}
\hline & \multicolumn{6}{|c|}{$\begin{array}{c}\text { Site 6 } \\
(\mathrm{CHZ} 142012-13)^{\dagger}\end{array}$} & \multicolumn{6}{|c|}{$\begin{array}{c}\text { Site } 7 \\
(\mathrm{CHZ} 132012-13)\end{array}$} \\
\hline & \multicolumn{2}{|c|}{ Snare } & \multicolumn{2}{|c|}{ Shotgun } & \multicolumn{2}{|c|}{ Other } & \multicolumn{2}{|c|}{ Snare } & \multicolumn{2}{|c|}{ Shotgun } & \multicolumn{2}{|c|}{ Other } \\
\hline & Catch & Prop & Catch & Prop & Catch & Prop & Catch & Prop & Catch & Prop & Catch & Prop \\
\hline $\begin{array}{l}\text { Blue duiker } \\
\text { (Philantomba monticola) }\end{array}$ & 107 & 0.50 & 12 & 0.27 & & & 24 & 0.57 & 102 & 0.41 & 1 & 0.04 \\
\hline $\begin{array}{l}\text { Peter's duiker }{ }^{\star} \\
\text { (Cephalophus callipygus) }\end{array}$ & 19 & 0.09 & 1 & 0.02 & & & 4 & 0.10 & 3 & 0.01 & 1 & 0.04 \\
\hline $\begin{array}{l}\text { Bay duiker }{ }^{*} \\
\text { (C. dorsalis) }\end{array}$ & 16 & 0.08 & 1 & 0.02 & & & 2 & 0.05 & 5 & 0.02 & & \\
\hline $\begin{array}{l}\text { Black-fronted duiker } \\
\text { (C. nigrifrons) }\end{array}$ & 2 & 0.01 & & & & & & & & & & \\
\hline $\begin{array}{l}\text { Yellow-backed duiker } \\
\text { (C. silvicultor) }\end{array}$ & 2 & 0.01 & & & & & 1 & 0.02 & & & & \\
\hline $\begin{array}{l}\text { Red river hog } \\
\text { (Potamochoerus porcus) }\end{array}$ & 2 & 0.01 & & & & & 1 & 0.02 & 1 & 0.00 & & \\
\hline $\begin{array}{l}\text { Brush-tailed porcupine } \\
\text { (Atherurus africanus) }\end{array}$ & 25 & 0.12 & 1 & 0.02 & 1 & 0.07 & 2 & 0.05 & 3 & 0.01 & & \\
\hline $\begin{array}{l}\text { Giant pouched rat } \\
\text { (Cricetomys sp.) }\end{array}$ & 11 & 0.05 & & & & & 4 & 0.10 & & & 2 & 0.08 \\
\hline Monkeys & 4 & 0.02 & 26 & 0.59 & 1 & 0.07 & & & 130 & 0.52 & & \\
\hline Other & 25 & 0.12 & 3 & 0.07 & 13 & 0.87 & 4 & 0.10 & 5 & 0.02 & 20 & 0.83 \\
\hline Total & 213 & 1.00 & 44 & 1.00 & 15 & 1.00 & 42 & 1.00 & 249 & 1.00 & 24 & 1.00 \\
\hline
\end{tabular}

$\mathrm{B} / \mathrm{M}$ was 2.31 for site 5 and 2.89-12.75 for sites 6 and 7, whereas the density $\mathrm{B} / \mathrm{M}$ remained at around 0.70 for $\mathrm{CHZs} 13$ and 14 . This implies that blue duikers were selectively captured in these sites.

The reason for the high values of catch $\mathrm{B} / \mathrm{M}$ for gun hunting is likely related to the different behaviors among duikers. When hunting duikers with guns at night, hunters generally entice the target by imitating the bleating call of the animal (Brosset 1966). Blue duikers respond well to this approach because they become active at night in a disturbed forest and are reluctant to leave their small home range (Kingdon 1997, Hart and Kingdon 2013). Hunters reported that blue duikers tended to freeze when they were caught in the beam of a flashlight, making it easy to shoot them. In contrast, Peter's duikers, the major species of mediumsized duiker, are active in the daytime, inhabit a larger home range than do blue duikers, and are more likely to flee from humans (Noss 2000, Feer and Mockrin 2013). It is therefore likely that encounters with Peter's duiker are limited for hunters using guns both in the the day and at night.

In the case of snare hunting, however, the hunting technology itself does not seem to drive the deviation of the catch $\mathrm{B} / \mathrm{M}$ from the density $\mathrm{B} / \mathrm{M}$. In fact, the catch $\mathrm{B} / \mathrm{M}$ for sites $1-3$ corresponded closely to the density $\mathrm{B} / \mathrm{M}$ in the same area. A possible reason for the deviation is that the exact densities within the areas where hunting was carried out also deviated from the densities we used, which were estimated as an average over an extensive area. In fact, a large proportion of the catches of the Konabembe hunters in sites 6 and 7 were obtained in areas near the villages, which likely contained compositions of duikers different from those in the other areas where the hunting pressure was more moderate. In the case of site 5 , although the catches were made from forest camps, the population in Gribé (approximately 800 people) far exceeded that in ZA (170 people), the nearest village to sites 1-4. Consequently, the composition of duikers in the area frequently used for snaring is likely to deviate from that estimated for the entire area of $\mathrm{CHZ} 14$.

In addition, the snaring strategy may affect the catch composition. When hunters target medium-sized duikers, they use wires that are unwound into two pieces from a brand-new wire. Finer wires are available for capturing blue duikers, although medium-sized duikers can break through them. When hunters choose an area with fewer medium-sized duikers, they unwind wires into finer strands so as to make more snares from a single roll of wire. Consequently, once the proportion of blue duiker increases in catches, the hunters are likely to set more snares with finer wires, from which medium-sized duikers can escape, and blue duikers are caught selectively.

In summary, the trend of changes in the catch $\mathrm{B} / \mathrm{M}$ and density $\mathrm{B} / \mathrm{M}$ in southeastern Cameroon can be described by the following points (see also Fig. 3):

1. Without substantive human intervention, i.e., hunting pressure and forest disturbance, medium-sized duikers are densely distributed and blue duikers are sparse, so that both catch $\mathrm{B} / \mathrm{M}$ and density $\mathrm{B} / \mathrm{M}$ are low. This pattern was observed at sites 1-3.

2. Under moderate human intervention, blue duikers become more densely distributed while the original density of medium-sized duikers is maintained, so that the catch $\mathrm{B} / \mathrm{M}$ increases with increasing density $\mathrm{B} / \mathrm{M}$. This trend was observed at site 4 . 
Table 6. Catch of blue and medium-sized duikers and catch $\mathrm{B} / \mathrm{M}$ at sites $1-7$.

\begin{tabular}{|c|c|c|c|c|c|c|c|c|c|}
\hline & \multirow{2}{*}{$\begin{array}{l}\text { Site } 1 \\
\text { Snare } \\
\end{array}$} & \multirow{2}{*}{$\begin{array}{l}\text { Site } 2 \\
\text { Snare } \\
\end{array}$} & \multirow{2}{*}{$\begin{array}{l}\text { Site } 3 \\
\text { Snare }\end{array}$} & \multirow{2}{*}{$\begin{array}{l}\text { Site } 4 \\
\text { Snare }\end{array}$} & \multirow{2}{*}{$\begin{array}{l}\text { Site } 5 \\
\text { Snare }\end{array}$} & \multicolumn{2}{|c|}{ Site 6} & \multicolumn{2}{|c|}{ Site 7} \\
\hline & & & & & & Snare & Gun & Snare & Gun \\
\hline $\begin{array}{l}\text { Blue duiker } \\
\text { (Philantomba } \\
\text { monticola) }\end{array}$ & 2 & 22 & 13 & 18 & 65 & 107 & 12 & 24 & 102 \\
\hline $\begin{array}{l}\text { Medium-sized duikers } \\
\text { (Cephalophus spp.) }\end{array}$ & 65 & 345 & 141 & 32 & 27 & 37 & 2 & 6 & 8 \\
\hline Catch B/M & 0.03 & 0.06 & 0.09 & 0.56 & 2.31 & 2.89 & 6.00 & 4.00 & 12.75 \\
\hline
\end{tabular}

Catch $\mathrm{B} / \mathrm{M}$ indicates the ratio of blue to medium-sized duikers for the total number of hunting catches.

3. With extensive human intervention in specific areas, medium-sized duikers are sparsely distributed while the density of blue duikers remains relatively high, and the catch $\mathrm{B} / \mathrm{M}$ becomes much higher than that in point 2 . A deviation between the catch $\mathrm{B} / \mathrm{M}$ and the density $\mathrm{B} / \mathrm{M}$ appears to be caused by a mosaic of different compositions of duikers formed over an extensive area. This trend was observed at sites 5 and 6 .

4. With extensive human intervention extending over the specific extensive area, both medium-sized and blue duikers become sparse. When animals become too sparse to be caught sufficiently frequently in snares, it makes sense more and more to search for efficient targets with guns. This was observed in site 7 .

Fig. 3. Model of changes in the density of blue duikers (Philantomba monticola) and medium-sized duikers (Cephalophus spp.) in accordance with time passed under intensive hunting pressure. Labels of sites 1-7 indicate the approximate situations of these sites. The reasons for the deviations of the ratio of blue to medium-sized duikers for the total number of hunting catches (catch $\mathrm{B} / \mathrm{M}$ ) are discussed in the text. Density B/M indicates the blue duiker/medium-sized duiker density ratios.

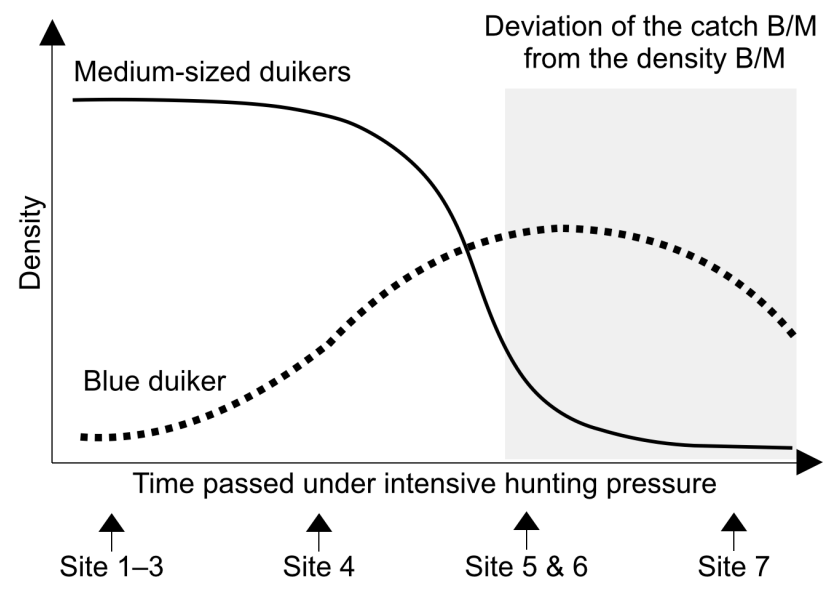

It is notable that when hunting pressure increases moderately within a certain limit, the density of duikers as a whole, as well as the catch effort, can remain unchanged. However, even in this case, the biomass both in the wild and in the catches may decrease. In other words, during the initial phase of hunting activity, it is not the total number of individuals but rather the biomass in the area that is affected by strengthened human interventions. Additionally, it is noteworthy that point 1 above does not necessarily represent the original state everywhere across the Congo Basin. Indeed, the density of blue duikers exceeded that of medium-sized duikers even in less disturbed areas in some countries (Yasuoka 2014).

\section{A collaborative wildlife management approach based on the catch B/M}

According to regulations enacted by the Cameroon Government (1994, 1995), hunting by local people is prohibited in protected areas. Even outside these areas, i.e., in $\mathrm{CHZs}$, unrestricted hunting is permitted only under the following conditions: (1) the hunting must only target species that are excluded from the list of protected animals, which contains, e.g., Peter's duiker, bay duiker, yellowbacked duiker, and red river hogs; (2) it must rely solely on "traditional" implements; and (3) it must only be used for household consumption. The law defines traditional implements as those made of plant materials, which exclude steel wires and guns. Consequently, most of the animals hunted in sites 1-4 are protected, and the hunting is illegal. In sites 5-7, a large proportion of the catches, including blue duikers, is composed of animals not on the protected species list, but the hunting technologies used are illegal.

As noted by Bennett et al. (2007), although laws that regulate hunting of wild animals exist in African countries, in practice wildlife is usually an open access resource that anyone can harvest. Because snare hunting is limited primarily by the availability of steel wire rather than the intensive commitment of labor required, the prevalence of snare hunting increases immediately when hunters obtain rolls of wire. In fact, when the logging road was opened to ZA in 2002, the bushmeat catch increased by a factor of 5-10, reaching an unsustainable level (Yasuoka 2006a). It was therefore inevitable that controls over the bushmeat trade and hunting were introduced.

However, as previously mentioned, initial approaches to wildlife management, including harsh control of subsistence hunting by local people, were criticized for lacking consideration of their customary rights to the forest resources. Subsequently, a variety 
Table 7. Density estimations of blue and medium-sized duikers and density B/M in Nki NPs and and CHZs 14 and 13.

\begin{tabular}{|c|c|c|c|c|c|}
\hline & $\begin{array}{l}\text { Nki area }{ }^{\dagger} \\
\text { Mid-1990s }\end{array}$ & $\begin{array}{c}\text { Corridor area }^{\dagger} \\
\text { Mid-1990s }\end{array}$ & $\begin{array}{l}\text { Nki NPs }{ }^{\ddagger} \\
\text { Mid-2000s }\end{array}$ & $\begin{array}{c}\text { CHZ } 14^{\S} \\
\text { Early } 2010 \\
\end{array}$ & $\begin{array}{c}\text { CHZ } 13^{\S} \\
\text { Early } 2010 \\
\end{array}$ \\
\hline $\begin{array}{l}\text { Blue duiker } \\
\text { (Philantomba monticola) }\end{array}$ & 0.1 & 0.4 & 2.8 & 4.9 & 1.6 \\
\hline $\begin{array}{l}\text { Medium-sized duikers } \\
\text { (Cephalophus spp.) }\end{array}$ & 6.0 & 5.3 & 6.8 & 7.2 & 2.3 \\
\hline Density B/M & 0.02 & 0.08 & 0.41 & 0.68 & 0.70 \\
\hline
\end{tabular}

of projects were proposed to ensure the active participation of local people in the management initiatives. However, because the local people were unfamiliar with the concepts of conservation ecology, it was difficult for them to engage effectively in the management projects.

An approach based on the catch $\mathrm{B} / \mathrm{M}$ can provide an effective point of departure that renders the participation of local people more practical and meaningful. The catch $\mathrm{B} / \mathrm{M}$ can be observed with little additional effort through the daily activities of local hunters. It is also helpful for ecologists engaged in wildlife management, because it can provide a reasonable prediction of the density $\mathrm{B} / \mathrm{M}$ and possibly the status of wild fauna populations. Furthermore, this approach can compensate for the limitations in the existing wildlife management schemes that seem to depend on limited and often contradictory information about both the fauna and hunting activities of the local people (van Vliet and Nasi 2008b, Viquerat et al. 2012). Despite the fact that animal densities provide one of the most important indicators on which any wildlife management plan is based, a single estimation of the density is not very reliable because it fluctuates fairly widely depending on the estimation method. Moreover, it is expensive to carry out periodic censuses, so that the feasibility of continuous monitoring of the status of wild fauna populations is largely dependent on the availability of funds. If the approach based on the catch $\mathrm{B} / \mathrm{M}$ can be integrated with conventional methods ( $\mathrm{Fa}$ and Brown 2009), this will render continuous monitoring more reliable and feasible, and at the same time provide invaluable information on hunting by local people.

To implement this approach successfully, it is essential to establish a relationship of trust between ecologists and local hunters. It is a considerable challenge to mediate between ecologists, with their scientific perspectives, and local people, who see their surroundings in a very different way based upon their culture as forest inhabitants. Initially, the perspectives of local hunters would appear erroneous from an ecological science point of view, and vice versa. However, the management approach based on the catch $\mathrm{B} / \mathrm{M}$ can facilitate understanding between the two parties. With the aid of forums that enable discussion of the reasons for increases in the catch $\mathrm{B} / \mathrm{M}$, ecologists and local people can address topics such as whether the catch $\mathrm{B} / \mathrm{M}$ realistically reflects the background fauna population, when gun hunting is more effective than snare hunting, which value should be considered as unacceptable, and when hunting should be suspended, among others. We should also pay attention to the diversity and inconsistency of the ideas among different groups of local peoples, between which unequal power relationships (i.e., those between the Baka and the Bantu peoples) have historically developed. To tackle these problems, comparative ethnozoological studies should be carried out on indigenous knowledge of animal behavior and ecology, and on people's own hunting behavior and strategies. Once the different actors reach a better understanding among themselves and a general consensus is reached, an effective collaborative wildlife management initiative can be implemented.

Responses to this article can be read online at: http://www.ecologyandsociety.org/issues/responses. $\mathrm{php} / 8041$

\section{Acknowledgments:}

This research was supported by JST/JICA, SATREPS (FOSAS project), and JSPS KA-KENHI (Nos. 22241057 and 24710296). The arguments were brushed up via the ATBC Annual Meeting 2014, with the financial support of CIFOR.

\section{LITERATURE CITED}

Althabe, G. 1965. Changements sociaux chez les Pygmées Baka de 1'Est-Cameroun. Cahiers d'Etudes Africaines 5(20):561-592. http://dx.doi.org/10.3406/cea.1965.3050

Bailey, R. C., and R. Aunger, Jr. 1989. Net hunters vs. archers: variation in women's subsistence strategies in the Ituri Forest. Human Ecology 17(3):273-297. http://dx.doi.org/10.1007/ $\underline{\mathrm{BF} 00889020}$

Bennett, E. L., E. Blencowe, K. Brandon, D. Brown, R. W. Burn, G. Cowlishaw, G. Davies, H. Dublin, J. E. Fa, E. J. MilnerGulland, J. G. Robinson, J. M. Rowcliffe, F. M. Underwood, and D. S. Wilkie. 2007. Hunting for consensus: reconciling bushmeat harvest, conservation, and development policy in West and Central Africa. Conservation Biology 21(3):884-887. http://dx. doi.org/10.1111/j.1523-1739.2006.00595.X

Bikie, H., J.-G. Collombo, L. Djombo, S. Minnemeyer, R. Ngoufo, and S. Nguiffo. 2000. An overview of logging in Cameroon. World Resources Institute, Washington, D.C., USA. 
Bobo, K. S., T. O. W. Kamgaing, B. C. Ntumwel, D. Kagalang, P. N. J. Kengne, S. M. L. Ndengue, M. M. N. Badjeck, and F. F. M. Aghomo. 2014. Species richness, spatial distributions and densities of large- and medium-sized mammals in the northern periphery of Boumba-Bek National Park, southeastern Cameroon. African Study Monographs Supplementary Issue 49:91-114.

Brosset A. 1966. un comportement énigmatique: pourquoi l'antilope vient-elle à l'appel du chasseur gabonais? Biologica Gabonica 2(3):287-290.

Davies, G., and D. Brown, editors. 2007. Bushmeat and livelihoods: wildlife management and poverty reduction. Blackwell, Malden, Massachusetts, USA. http://dx.doi.org/10.1002/9780470692592

Debroux, L., T. Hart, D. Kaimowitz, A. Karsenty, and G. Topa. 2007. Forests in post-conflict Democratic Republic of Congo: analysis of a priority agenda. A joint report by teams of the World Bank, Center for International Forestry Research (CIFOR), Centre International de Recherche Agronomique pour le Développement (CIRAD), African Wildlife Foundation (AWF), Conseil National des ONG de Développement du Congo (CNONGD), Conservation International(CI), Groupe de Travail Forêts (GTF), Ligue Nationale des Pygmées du Congo (LINAPYCO), Netherlands Development Organisation (SNV), Réseau des Partenaires pour l'Environnement au Congo (REPEC), Wildlife Conservation Society (WCS), Woods Hole Research Center (WHRC), World Agroforestry Centre (ICRAF) and World Wide Fund for Nature (WWF). CIFOR, Bogor, Indonesia.

Ekobo, A. 1998. Large mammals and vegetation surveys in the Boumba-Bek and Nki project area. WWF Cameroon, Yaoundé, Cameroon.

Fa, J. E., and D. Brown. 2009. Impacts of hunting on mammals in African tropical moist forests: a review and synthesis. Mammal Review 39(4):231-264. http://dx.doi.org/10.1111/j.1365-2907.2009.00149. $\underline{\mathrm{x}}$

Fa, J. E., C. A. Péres, and J. Meeuwig. 2002. Bushmeat exploitation in tropical forests: an international comparison. Conservation Biology 16(1):232-237. http://dx.doi.org/10.1046/j.1523-1739.2002.00275. $\underline{\mathrm{x}}$

Fa, J. E., S. F. Ryan, and D. J. Bell. 2005. Hunting vulnerability, ecological characteristics and harvest rates of bushmeat species in Afrotropical forests. Biological Conservation 121:167-176. http://dx.doi.org/10.1016/j.biocon.2004.04.016

Feer, F., and M. Mockrin. 2013. Cephalophus callipygus Peter's Duiker. Pages 279-281 in J. Kingdon and M. Hoffmann, editors. The mammals of Africa. Volume VI. Pigs, hippopotamuses, chevrotain, giraffes, deer and bovids. Bloomsbury, New York, New York, USA.

Fimbel, C., B. Curran, and L. Usongo. 2000. Enhancing the sustainability of duiker hunting through community participation and controlled access in the Lobéké region of southeastern Cameroon. Pages 356-374 in J. G. Robinson and E. L. Bennett, editors. Hunting for sustainability in tropical forest. Colombia University Press, New York, New York, USA.
Fogue, I., and L. Defo 2006. Environnement socio-economique du secteur Gribé-Ngatto Nouveau: Travaux d'evaluation de base et d'orientation du processus de gestion durable et de certification. WWF Cameroon, Yaoundé, Cameroon.

Government of Cameroon. 1994. To lay down forestry, wildlife and fisheries regulations. Law No. 94-01 of 20 January 1994. Government of Cameroon, Yaoundé, Cameroon.

Government of Cameroon. 1995. To lay down the conditions for the implementation of wildlife regulations. Decree No. 95-466-PM of 20 July 1995. Government of Cameroon, Yaoundé, Cameroon

Halle, B. 2000. Résumé des données socio-économiques du milieu rural au Sud-Est du Cameroun. Deutsche Gesellschaft fur Tchnische Zusammenarbeit (GTZ), Eschborn, Germany.

Harako, R. 1976. The Mbuti as hunters: a study of ecological anthropology of the Mbuti Pygmies. Kyoto University African Studies 10:37-99.

Hart, J. A., and J. Kingdon. 2013. Philantomba monticola Blue Duiker. Pages 228-234 in J. Kingdon and M. Hoffmann, editors. The mammals of Africa. Volume VI. Pigs, hippopotamuses, chevrotain, giraffes, deer and bovids. Bloomsbury, New York, New York, USA.

Hattori, S. 2005. Nature conservation and hunter-gatherers' life in Cameroonian rainforest. African Study Monographs Supplementary Issue 29:41-51.

Hattori, S. 2014. Current issues facing the forest people in southeastern Cameroon: the dynamics of Baka life and their ethnic relationship with farmers. African Study Monographs Supplementary Issue 47:97-119.

Hewlett, B. S. 1996. Cultural diversity among African Pygmies. Pages 215-244 in S. Kent, editor. Cultural diversity among twentieth-century foragers: an African perspective. Cambridge University Press, Cambridge, UK.

Hoare, A. 2006. Divided forests: towards fairer zoning of forest Lands. Rainforest Foundation, London, UK.

Ichikawa, M. 2006. Problems in the conservation of rainforests in Cameroon. African Study Monographs Supplementary Issue 33:3-20.

Ichikawa, M. 2014a. Forest conservation and indigenous peoples in the Congo Basin: new trends toward reconciliation between global issues and local interest. Pages 321-342 in B. S. Hewlett, editor. Hunter-gatherers of the Congo Basin: cultures, histories, and biology of African Pygmies. Transaction, New Brunswick, New Jersey, USA.

Ichikawa, M. 2014b. How to integrate a global issue of forest conservation with local interests: introduction to the SATREPS project in southeastern Cameroon. African Study Monographs Supplementary Issue 49:3-10.

Kingdon, J. 1997. The Kingdon field guide to African mammals. Academic Press Natural World, San Diego, California, USA.

Kingdon, J., and M. Hoffmann, editors. 2013. The mammals of Africa. Volume VI. Pigs, hippopotamuses, chevrotain, giraffes, deer and bovids. Bloomsbury, New York, New York, USA. 
Lewis, J. 2012. Technological leap-frogging in the Congo Basin, Pygmies and global positioning systems in central Africa: what has happened and where is it going? African Study Monographs, Supplementary Issue 43:15-44.

Letouzey, R. 1985. Carte phytogéographique du Cameroun au 1:500000. Institute de la Recherche Agronomique (Herbier National), Toulouse, France.

Mertens, B., G. N. Shu, M. Steil, and B. Tessa. 2012. The interactive forest atlas of Cameroon. Volume 3. World Resources Institute, Washington, D.C., USA.

Nasi, R., D. Brown, D. Wilkie, E. Bennett, C. Tutin, G. van Tol, and T. Christophersen. 2008. Conservation and use of wildlifebased resources: the bushmeat crisis. Secretariat of the Convention on Biological Diversity and Center for International Forestry Research (CIFOR), Bogor, Indonesia, and Montreal, Canada.

Nasi, R., A. Taber, and N. van Vliet. 2011. Empty forests, empty stomachs? Bushmeat and livelihoods in the Congo and Amazon Basins. International Forestry Review 13(3):355-368. http://dx.doi. org/10.1505/146554811798293872

Njounan-Tegomo, O., L. Defo, and L. Usongo. 2012. Mapping of resource use area by the Baka Pygmies inside and around Boumba-Bek National Park in southeast Cameroon, with special reference to Baka's customary rights. African Study Monographs Supplementary Issue 43:45-59.

Noss, A. 2000. Cable snares and nets in the Central African Republic. Pages 282-304 in J. G. Robinson and E. L. Bennett, editors. Hunting for sustainability in tropical forest. Colombia University Press, New York, New York, USA.

Nzooh-Dongmo, Z. L., B. Tchikangwa, A. Ngniado, L. Usongo, J. C. Ndo, and M. Dandjouma. 2002. Le système de suivi ecologique dans la région du Sud-Est Cameroun: axes d'intervention. World Wildlife Fund/Ministry of Environment and Forestry (Cameroon), Yaoundé, Cameroon.

Nzooh-Dongmo, Z. L., S. Kouob-Begne, V. Annong, C. Bassama, E. Fouda, and J. P. Mahop. 2006. Suivi ecologique dans le Parc National de Nki et sa zone périphérique: données de base sur la dynamique des populations de grands et moyens mammifères et des activités anthropiques. World Wildlife Fund/Cameroon Country Program Office/Jengi South East Forest Project, Yaoundé, Cameroon.

Robinson, J. G., and E. L. Bennett, editors. 2000. Hunting for sustainability in tropical forest. Colombia University Press, New York, New York, USA.

Seber, G. A. F. 1982. The estimation of animal abundance and related parameters. Griffin, London, UK.

Toda, M. 2014. People and social organizations in Gribé, southeastern Cameroon. African Study Monographs Supplementary Issue 49:139-168.

van Vliet, N., and R. Nasi 2008a. Why do models fail to assess properly the sustainability of duiker (Cephalophus spp.) hunting in Central Africa? Oryx 42(3):392-399. http://dx.doi.org/10.1017/ $\underline{\mathrm{S} 0030605308000288}$ van Vliet, N., and R. Nasi. 2008b. Hunting for livelihood in northeast Gabon: patterns, evolution, and sustainability. Ecology and Society 13(2):33. [online] URL: http://www.ecologyandsociety. org/vol13/iss2/art33/

van Vliet, N., R. Nasi, and J. P. Lumaret. 2008. Factors influencing duiker dung decay in north-east Gabon: are dung beetles hiding duikers? African Journal of Ecology 47:40-47. http://dx.doi. org/10.1111/j.1365-2028.2007.00913.x

Viquerat, S. M. A., K. S. Bobo, M. Müller, C. Kiffner, and M. Waltert. 2012. Estimating forest duiker (Cephalophinae) density in Korup National Park: a case study on the performance of three line transect methods. South African Journal of Wildlife Research 42:1-10. http://dx.doi.org/10.3957/056.042.0110

White, L., and A. Edwards, 2000. Conservation research in the African rain forests: a technical handbook. Wildlife Conservation Society, New York, New York, USA.

Wilkie, D. S., and J. F. Carpenter. 1999. Bushmeat hunting in the Congo Basin: an assessment of impacts and options for mitigation. Biodiversity \& Conservation 8(7):927-955. http://dx. doi.org/10.1023/A:1008877309871

Wilson, V. J. 2001. Duikers of Africa: masters of the African forest floor: a study of Duikers-people-hunting and bushmeat. . Zimbi Books, Bulawayo, Zimbabwe.

Wright, S. J. 2003. The myriad consequences of hunting for vertebrates and plants in tropical forests. Perspectives in Plant Ecology, Evolution and Systematics 6:73-86. http://dx.doi. org/10.1078/1433-8319-00043

Yasuoka, H. 2006a. The sustainability of duiker (Cephalophus spp.) hunting for the Baka hunter-gatherers in southeastern Cameroon. African Study Monographs Supplementary Issue 33:95-120.

Yasuoka, H. 2006b. Long-term foraging expedition (molongo) among the Baka hunter-gatherers in the northwestern Congo Basin, with special reference to the "wild yam question." Human Ecology 34(2):275-296. http://dx.doi.org/10.1007/s10745-006-9017-1

Yasuoka, H. 2009. The variety of forest vegetations in southeastern Cameroon, with special reference to the availability of wild yams for the forest hunter-gatherers. African Study Monographs 30(2):89-119.

Yasuoka, H. 2012. Fledging agriculturalists? Rethinking the adoption of cultivation by the Baka hunter-gatherers. African Study Monographs Supplementary Issue 43:85-114.

Yasuoka, H. 2014. Snare hunting among Baka hunter-gatherers: implications for sustainable wildlife management. African Study Monographs Supplementary Issue 49:115-136. 